\title{
Usage of Big Data Technology in Controlling
}

\author{
Karolina Rybicka ${ }^{1}$ \\ ${ }^{1}$ Czestochowa University of Technology, Czestochowa, Poland \\ Correspondence: Karolina Rybicka, Czestochowa University of Technology, Armii Krajowej 19B, Czestochowa, \\ Poland. E-mail: karolina.rybicka@wz.pcz.pl
}

Received: October 24, 2019

Accepted: November 15, 2019

Online Published: December 22, 2019

doi:10.5430/rwe.v10n4p92

URL: https://doi.org/10.5430/rwe.v10n4p92

\begin{abstract}
Business units meet many dynamic and unexpected changes occurring in their surrounding. They want to be competitive and that is why they must deal with uncertainty and risk. Digital revolution is present in all societies. Changes caused by usage of new technologies based on ICT technologies and Internet change the business. Nowadays enterprises must adjust to new determinants and to introduce digital technologies into their management processes, controlling systems. Companies now require fast and accurate information.

Big Data technology brings to modern companies many technological opportunities. Big Data allows the creation of new business models, proper analysis of customer behavior, facilitates risk and financial management of the company, optimizes processes occurring inside the enterprise and increases the efficiency of IT systems operating in controlling of business unit.

The aim of the paper is to present some theoretical issues connected with the use of Big Data technology in businesses, especially within systems of controlling ("Controlling" in the meaning used by German speaking scientists). Digital revolution with usage of social media in business activity or Big Data technology changed the controlling systems, because now controllers must deal with such huge datasets to improve their businesses. With usage of Big Data technology, despite some challenges occurred, modern enterprises can deal with success with such large volume of data (not only financial, but now also non-financial) in order to proper better forecasts and decisions. There are presented some issues connected with usage of Big Data technology in controlling systems of companies.
\end{abstract}

Keywords: big data, controlling, ICT technology, IT system

\section{Introduction}

The development of new ICT technologies (information and communication technologies) totally transformed the way of people performances in the social and economic areas. This massive development of modern forms of communication, such as mobile telephony, e-mails, transmission of different, not only financial and monetary, data, photos, films, with no geographical limitation, deeply reduced the time needed for the same activities as some years ago. Such revolution also applies to business activities of companies. Nowadays, talking to a contractor located on another country or even continent is limited only to pulling the phone out of the pocket. With the support of a computer, tablet or phone, you can conduct video relations in a real time (Broek \& Veenstra, 2018), (Palvia et al., 2018), (Vaujany et al., 2018), (Talon-Ballestero et al., 2018), (Khatri et al., 2018).

Nowadays, the activities of companies are holistic, not limited only to current activities. In order to meet the requirements of being competitive in the contemporary global and constantly changing world, the companies should expand their business performance to a virtual environment in the digital space. The space in which enterprises operate is constantly growing. For this reason, all the time entrepreneurs need to learn new business solutions and implement new solutions to maintain the desired market position (Jelonek, 2004), (Townsend et al., 2018), (Ravichandran, 2018).

Modern enterprises are facing every day with many different data that can influence on the business activity. The volume of global data in next few years is expected to increase more than fifty times. Such situation is because of use of sensor technology in manufacturing and in logistics, and also widespread Internet. The necessity of dealing with large volume of data is now the key element of controllers' job. Controllers must deal with such data because of their responsibility for supply of proper information to managers, in order to provide better forecasts and decisions. 
The research problem of these considerations is an attempt to fulfill the gap in using Big Data in management processes of business units, especially in controlling. The idea of controlling was introduced in United States and next in 1950s the concept of controlling was implemented in German companies. This term is now rather used in German speaking countries, while English ones use rather the term "management accounting" (because "controlling" is for them rather "monitoring" than "steering"). Nowadays many scientists and practitioners discuss what controlling really is. They try to indicate differences between controlling and management accounting. In author's opinion now such terms can be synonymous. In this paper the term "controlling" is the same that "management accounting" in American or English literature. The term "controlling" used in the paper is based on German concept of this issue.

\section{Literature Review}

\subsection{Controlling in Management System}

Controlling is usually interpreted as a support for the managers in the decision-making process. Supporting the functions of management becomes a necessity if one takes into account the increasing complexity of the decision-making process. This includes the terms of increased demand for information and decision-making problems, as well as more and more complex management methods and instruments. There can be no controlling without management. System of controlling is very important and complex and that's why it makes sense to support managers in decision-making processes. There is the tight interaction between managers and controllers that constitutes controlling (ICV, 2012).

Because of dynamic development, the controlling can be an efficient instrument of management. There is the increasing need of managers for very quick and proper economic information, essential for decision-making processes. Nowadays, we can observe that contemporary controlling is more and more the important element of the management process, not only at the operational level, but also at the strategic one. Traditionally, controlling was defined as an enterprise information subsystem whose aim was to provide information to various users within an organization for the purpose of planning and making business decisions (Nowak, 2015). In a broader sense, it is treated as an integral part of management that identifies, presents and interprets various information used to create strategies, plan and control activities, make the right decisions, optimize the use of resources and provide them to relevant users of such information and controller should be a business partner for manager.

The basic task of controlling system is to provide financial and non-financial information for managers and is focused on supporting strategic management. Therefore, it is related to the settlement of the organization's strategy, long-term planning, strategic decision-making and strategic control. The growing importance of information flowing from the accounting system in the strategic management process has led to the development of strategic controlling, which is the decision-makers' use of an effective information system supporting the acquisition of competitive advantage by the company. Controlling is based on two elements: the choice the right strategy and the quality of the information system.

An important challenge facing today's controllers is to support the reaching of strategic goals of the organization. In order to achieve goals by implementing the adopted strategy, appropriate achievements should be demonstrated. That's why, it is important to properly measure the different performances of the entire enterprise.

The increase in the value of the company contributes to the increase of value for co-owners, improvement of the competitive position on the market and strengthening of the financial potential. The value creation on the background of enterprise development processes should be subject to continuous monitoring. The process of measurement in the area of controlling is also the subject to the value provided by the business unit to the customer and the value of the customer for the company (Lada, 2016).

Controlling plays a significant role in risk management and obtaining the company's performance. Contemporary enterprises run in a turbulent environment, therefore their future results are always subject to risk and uncertainty. That is why, it is very important to identify the risks of the company (Nowak, 2015). Risk management includes such stages as: identification of risk factors, assessment of the scale of a given risk, monitoring of risk modeling and reacting to emerging risks. The implementation of risk management requires informational support from controlling system. An appropriate management system has a wide range of instruments that allow to reduce the negative effects of risk and to take advantage of opportunities inherent in this company's risk.

The role of controlling has changed from directing primarily on budgeting, costing, variance analysis to developing and implementing strategies that promote increased company's performance while managing risk (Ramli, 2015). So that's why controllers now should know what facts about managers' performances and they also must know their 
information needs (Richins et al., 2017).

At the beginning of the 20th century, controllers became business partners in decision-making processes and solving business problems (it is stated by ICV association). The then-dominant methods of controlling are rather traditional methods (e.g. absorption costing), although they appeared to be inadequate to the changing conditions of contemporary business activity and did not provide relevant and reliable information (Nita, 2015).

Nowadays, financial controllers pay more attention to cost reduction, which seems more important than generating relevant cost information. Such results confirm a high level of expectations of controlling, which should be focused on improving processes and efficiency in order to reduce costs. Very important become also: implementation of ERP systems, new budgeting methods, and internal reporting.

There can be found proposals for directions of controlling development, such as: supporting strategic management, improvement of identification and analysis of investment projects, improvement of management systems, analysis of cost-generating factors, improving planning techniques in turbulent surrounding.

Mass digitization of measurement different economic phenomenon facilitates proper realization of controlling processes and causes their radical transformation. There are three main trends caused by Big Data (Łada, 2016; Łada, 2017):

- full automation of information processes and on-line bookkeeping,

- decrease of importance of money measurement and financial reporting for, so called, "raw data" of varied character,

- change the role of previous accountants to contemporary information systems designers.

Many scientists will try to formulate predictions about future directions of controlling development. What will be the main future trend? Undoubtedly, it seems to many scientists, continuous development of digital technologies.

\section{Challenges and Benefits of Big Data in Controlling}

One of the main functions of Big Data is to deliver accurate information to the managers in order to improve decision-making processes. Furthermore, as the supply of information for decision-makers is one of the basic functions of the controlling department, such information provision is the straight link between Big Data and controlling. Analytical methods for data analysis can be used to extract useful information for the decision-makers from Big Datasets. LaValle et al. (2011) distinguish between three levels of growth in the use of analytical methods: aspirational, experienced and transformed. Quality of data coming from Big Datasets seems to be the key factor of successful using such type of information in controlling. Successful data oriented decision-making process is only possible in case of veracity, if information is correct. Also well-defined and well-executed business processes are important feature to ensure the quality of such data. Shortcomings in data quality can lead to negative effects. For example inaccurate calculation of unit cost can increase total production costs. In this situation, managers lose their trust in such type of data and might return to relying on their own intuition only. Redman (2013) proposes three solutions for this problem with data quality: must be connection between data suppliers and data recipients, new data should be of a high quality, managers must be responsible for data quality.

The functions of controlling in terms of Big Data can be systematized using the "coordination-oriented approach of controlling". This approach emphases on the coordination of different areas of management, especially concerning information, planning, controlling, organization, human resources and value systems. Big Data technology has a direct effect on IT systems. Especially, the usage of Big Datasets supports the consideration of non-financial information together with financial information. Non-financial data are more complex and more heterogeneous with regard to origin and type. That's why a controller meets with two major tasks. Such evaluation is needed, because new information can potentially be generated for better understanding a business. Additional assessment is required: how to connect such information type to the existing data one. Controllers are rather skeptic when thinking about new solutions. Doubtful Big Data solutions should be approached with criticism (ICV, 2014).

Potential applications of Big Data technology should to be analyzed for the planning and controlling system as well. Issues such as forecasting, scenarios and early warning systems must be taken into account. Big Data can be used, for example, for valuation of fixed assets or for risk management and risk analysis. Such activity requires more creativity and an open mind towards new possibilities.

And in many business units it must be examined if existing controllers are really the accurate people to introduce Big Data technology and to take from these huge datasets proper information for decision-making processes. It must be also observed if Big Data also has real impact on a company's value. 
The role of controllers dealing with Big Data technology depends on their self-perception. Controllers can think that Big Data technology is an opportunity to transform into the role of business analysts as well as to extend their information reporting duties beyond the scope of traditional finance systems. There are many controlling processes that can be affected by Big Data technology, e.g.: strategic planning (increase of dynamics and complexity of managing of suppliers and consumers), operational planning (ensure usefulness of Big Data for operational control), business consulting and management (acquisition of knowledge of applications, solutions, databases, technologies, cloud computing solutions).

There are also changes in controlling, like new users of data - machines that can join different and enormously huge databases, and can process them into bases of algorithmic business decisions.

Usage more data can increase the power of analysis but it fails to remove inaccuracies or biases occurred in Big Data. Additionally, while obtaining sufficiently large databases, it is unsurprised to find spurious correlations. Although data analysts own skills to carry out the exploratory analyses identifying correlations and algorithms, management accountants' ability to understand the language of business provides them with the capability to identify and interpret relevant data that can be processed into strategies. Using big data analytics, controllers can broaden their controlling and monitoring techniques to include unstructured data providing the power to identify areas of improvement and some opportunities. Sentiment analytics, for instance, based on social media data (like Facebook, Instagram) can be merged with existing accounting data in order to develop sophisticated models (Richins et al., 2017).

Big Data technologies can support controllers to generate proper and usable information to improve decision-making processes. The requirement to handle increasing amount of data can significantly change contemporary management accounting. After analysis it can be stated that main opportunities with new technologies (like Big Data) for controlling are following: integration of new data channels, unstructured data, automatic generation of data, cost and time optimization, real-time data, improvement of operational and strategic planning, as well as improvement of decision support for highest level on managers. On the other hand, there are some challenges for controllers because of Big Data phenomenon: large volumes of data, overload of information, changing cost structure, faster false decisions, lack of resources (insufficient knowledge of personnel) (Gärtner and Hiebl, 2018).

\section{Discussion}

Big Data requirements go beyond traditional responsibilities of a controller. Such requirements are settles for business analysts or data scientists. But sometimes it can be unclear if it refers to new functions for financial controllers or if there are two completely new and separate jobs created for Big Data needs. Most companies have just started using Big Data technology. Most of topics are still in a growing stage. In the upcoming years it will be revealed the real importance of the business analyst or data scientist. Whether and which of those functions will be carried out by a controllers also depends on the type of company and on the specific controllers skills and knowledge. Nowadays, there are financial controllers in some companies, who are responsible for specialized areas inside the enterprise, while in other companies, all these functions are fulfilled by one controller. Especially, small and medium-sized enterprise will not have the capability to employ specialized business analysts and data scientists, in particular when they are at the beginning stage of implementation Big Data technology. It can be real challenge for future financial controllers.

The paper is an attempt to investigate the status quo of using Big Data in controlling systems. The research is at the beginning stage, so that is why there are presented only theoretical aspect of these issues. Future work of the author will be carried out among Polish manufacturing companies.

\section{References}

Adamczewski, P. (2017). Adaptacje systemów ICT nowoczesnych organizacji w procesie transformacji cyfrowej. Prace Naukowe Uniwersytetu Ekonomicznego we Wroclawiu No.475, 14-15.

Broek, T. V., \& Veenstra, A. F. (2018). Governance of big data collaborations: How to balance regulatory compliance and disruptive innovation. Technological Forecasting and Social Change, 129, 330-338. https://doi.org/10.1016/j.techfore.2017.09.040

Gärtner, B., \& Hiebl, M. R. W. (2018). Chapter 13. Issues with Big Data. In Quinn M., Strauss (Eds.), The Routledge Companion to Accounting Information Systems (2018, pp.5-10). Routledge.

Gonciarski, W. (2017). Koncepcja zarządzania 2.0 jako konsekwencja rewolucji cyfrowej. Studia Ekonomiczne. Zeszyty Naukowe Uniwersytetu Ekonomicznego w Katowicach, No.338, 45-46.

Höller, J., \& Tsiatsis, V. (2014). From Machine-to-Machine to the Internet of Things: Introduction to a New Age of 
Intelligence. Elsevier, p. 14.

ICV Report. (2012). Perspective of the International Controller Association (ICV) and the International Group of Controlling (IGC).

ICV Report. (2014). Big Data. Potencial for the Controller.

Jelonek, D. (2004). Wybrane źródła konkurencyjnej przewagi przedsiębiorstwa w przestrzeni internetowej. Polskie Stowarzyszenie Zarzadzania Wiedza, Seria Studia i Materiaty, No. 3, 19-26.

Khatri, V., Samuel, B. M., \& Dennis, A. R. (2018). System 1 and System 2 cognition in the decision to adopt and use a new technology. Information \& Management, 55(6), 709-724.https://doi.org/10.1016/j.im.2018.03.002

Łada, M. (2016). Automatyzacja procesów rachunkowości zarządczej. Prace Naukowe Uniwersytetu Ekonomicznego we Wroctawiu, No.440, 203.

Łada, M. (2017). Od konsekwencji do antecedencji - zmiana orientacji pomiaru we współczesnej rachunkowości. Zeszyty Teoretyczne Rachunkowości, tom, 92(148), 87.

LaValle, S., Lesser, E., Shockley, R., Hopkins, M. S., \& Kruschwitz, N. (2011). Big data, analytics and the path from insights to value. MIT Sloan Management Review, 52(2), 21-32.

Marz, N., \& Warren, J. (2016). Big Data. Najlepsze praktyki budowy skalowalnych systemów obsługi danych w czasie rzeczywistym. Helion, Gliwice, p.17.

Mateos, A., \& Rosenberg, J. (2011). Chmura obliczeniowa. Rozwiqzania dla biznesu, Helion, Gliwice, p.260.

Mayer-Schönberger, V., \& Cukier, K. (2017). Big Data. Rewolucja, która zmieni nasze myślenie, pracę i życie, efektywna analiza danych, MTBiznes, Warszawa, pp.19-20.

McAfee, A., \& Brynjolfsson, E. (2012). Big Data. The Management Revolution. Harvard Business Review, (90), 118.

Nita, B. (2015). Stan i perspektywy rozwoju rachunkowości zarządczej w XXI wieku w praktyce. Prace Naukowe Uniwersytetu Ekonomicznego we Wrocławiu, (399), 365-366.

Nowak, E. (2015). Tendencje rozwoju systemów rachunkowości zarządczej, Zeszyty Naukowe Uniwersytetu Szczecińskiego No 873. Finanse, Rynki Finansowe, Ubezpieczenia, (77), 403-404.

Palvia, P., Baqir, N., \& Nemati, H. (2018). ICT for socio-economic development: A citizens' perspective. Information \& Management, 55(2), 160-176. https://doi.org/10.1016/j.im.2017.05.003

Perera, Ch., Ranjan, R., Wang, L., Khan, S. U., \& Zomaya, A.Y. (2015, May/June). Big Data Privacy in the Internet of Things Era. IT Pro, pp. 32-39.

Ramli, A., Sulaiman, S., \& Zainuddin, Z. N. (2015). Factors Driving Change in Management Accounting Practices: Malaysian Survey Evidence. Springer, Singapore, pp. 475-490.

Ravichandran, T. (2018). Exploring the relationships between IT competence, innovation capacity and organizational agility. The Journal of Strategic Information Systems, 27(1), 22-42. https://doi.org/10.1016/j.jsis.2017.07.002

Redman, T. C. (2013). Data's Credibility Problem. Management - not technology - is the solution. Harvard Business Review, 10, 84-88.

Richins, G., Stapleton, A., Stratopoulos, T. C., \& Wong, C. (2017). Big Data Analytics: Opportunity or Threat for the Accounting Profession?. Journal of Information Systems, 31(3), Fall, 12-15.

Talón-Ballestero, P., González-Serrano, L., Soguero-Ruiz, C., Muñoz-Romero, S., \& Rojo-Álvarez, J. L. (2018). Using big data from Customer Relationship Management information systems to determine the client profile in the hotel sector. Tourism Management, 68, 187-197. https://doi.org/10.1016/j.tourman.2018.03.017

Townsend, M., Quoc, T. L., Kapoor, G., Hu, H., Zhou, W., \& Piramuthu, S. (2018). Real-Time business data acquisition: How frequent is frequent enough?. Information \& Management, 55(4), 422-429. https://doi.org/10.1016/j.im.2017.10.002

Vaujany, F. D., Fomin, V. V., Haefliger, S., \& Lyytinen, K. (2018). Rules, Practices, and Information Technology: A Trifecta of Organizational Regulation. Information Systems Research, 29(3), 755-773. https://doi.org/10.1287/isre.2017.0771 